\title{
Potential Impact of U.S. Re-Emerging Rare Earths Industry on Future Global Supply and Demand Trend
}

\author{
Chunyan $\mathrm{He}^{1} \&$ Yalin Lei ${ }^{1}$ \\ ${ }^{1}$ School of Humanities and Economic Management, China University of Geosciences (Beijing), Beijing, China \\ Correspondence: Yalin Lei, School of Humanities and Economic Management, China University of Geosciences \\ (Beijing), Beijing, 100083, China. Tel: 86-10-8232-3525. E-mail: leiyalin@cugb.edu.cn
}

Received: April 10, 2013

Accepted: May 13, $2013 \quad$ Online Published: June 14, 2013

doi:10.5539/ibr.v6n7p44

URL: http://dx.doi.org/10.5539/ibr.v6n7p44

\begin{abstract}
Recently, based on the rapid growth of internal markets and limited reserves, some REEs have been in a supply shortage, especially HREEs. Thus, how to get new REs production sites and supply chain becomes an urgent global problem. U.S. government announced the resumption of production of domestic REs ores in 2012 to respond to the increasing internal demand for and contracting supply of REs. Aiming to explore U.S. re-emerging REs industry's potential impact on future global REs supply and demand trend, this paper reviews the current global REs supply and demand and U.S. re-emerging REs industry and then forecast and analyze the future impact of U.S. re-emerging REs industry on global REs supply and demand trend using Documentary Research Method. The result is that U.S. re-emerging REs industry will lead to a significant impact of supply surplus in total on future global and its internal REs demands. Nonetheless, the global including U.S. demand of HREEs will still rely on China's supply. The results will provide references to the development of U.S.'s REs industry and China's industrial policies. It will also make contribution on improving global REs supply and demand relationship.
\end{abstract}

Keywords: re-emerging, U.S. rare earths, impact, supply and demand trend

\section{Introduction}

\subsection{Background}

The United States (U.S.) was the leading producer of rare earths (REs) from 1940s to mid-1980s, when it provided the majority of REs to the rest of world (ROW) from the Mountain Pass mine in California which is one of the best minable deposits in the world (Gschneidner, 2011; Morrison \& Tang, 2012). However, during the 1990s, China's REs production increased drastically. With the abundant and low-price REs supplies from China, Mountain Pass was unable to compete. Moreover, given the mine's increasing ecological costs as a result of a halt in chemical processing in 1998 on the back of a series of wastewater leaks, operations ended in 2002 (Currie, 2012).

Thus, China has become the world's dominant producer, user, and exporter of REs in the recent decade, which accounts for $97 \%$ of global REs production (Cordier, 2012). U.S., like many other countries, has nearly become mainly dependent on China's REs export. Recently, based on the rapid growth of internal markets and limited reserves, especially the heavy rare earth elements (HREEs), Chinese government begins to control the overheated REs production and export by means of some policies such as export quotas and export licenses which result in the soaring REs export prices. Therefore, as the third largest REs consumer in the world, U.S. government has conducted a series of strategies in respond to the increasing internal demand and contracting supply of REs. Re-opening REs industry is one of its responds. In 2008, Molycorp Minerals, LLC purchased the Mountain Pass mine and it has been in full production since the end of 2012. Moreover, other REs projects such as Brokan and the Bear Lodge has already started or being prepared in the U.S.

\subsection{Study Purpose and Significance}

In view of the background, aiming to explore U.S. re-emerging REs industry's potential impact on future global REs supply and demand trend, and using Documentary Research Method, this paper will review the current global REs supply and demand and U.S. re-emerging REs industry and then forecast and analyze the future impact of U.S. re-emerging REs industry on global REs supply and demand trend. The results will provide 
references for the development of U.S.'s REs industry and China's industrial policies, and meanwhile also will contribute to improving global REs supply and demand relationship.

\subsection{Methodology}

Documentary Research Methods refers to the analysis of documents that contain information about the phenomenon we wish to study (Bailey, 1994). There are two types of documents that are used in documentary study, namely primary documents and secondary documents. In this paper, the latter will be used. This method is just as good, and sometimes even more cost effective than social surveys, in-depth interviews or participant observation (Mogalakwe, 2006). But this method has the high requirement for the documents. According to the quality control criteria for handling documentary sources formulated by Scott (1990), documents need to meet the following criteria: authenticity, credibility, representativeness and meaning.

Since there are a great number of authoritative forecast data about the future REs supply and demand of U.S. and the world have been published, it is appropriate to utilize a Documentary Research Method in this paper for analyzing the future impact of U.S. re-emerging REs industry on global REs supply and demand trend.

\section{Overview of the Current Global REs Supply and Demand}

\subsection{Total Rare Earth Oxide (REO)}

In the recent decade, China keeps the near-monopoly position in the supply of REs. Table 1 below shows that $97 \%$ of the global REs outputs are from China; however, it only has $50 \%$ of the global known reserves (55 million metric tons out of 110 million metric tons). From this table, we observe that REs reserves are dispersed throughout the world in fact, so China's REs reserves and supply relation is not in balance obviously. Those countries such as the U.S., Austria and India each have millions of metric tons of REs available to satisfy their own demands. According to Hendrick and Cordier (2010), there are sufficient world reserves to meet the forecasted increases in consumption for the foreseeable future. However, the fact is that such wealth of REs reserves still cannot mitigate the current crisis of the increasingly severe REs supply shortage. This is because most REs reserves holders only produce few REs due to reasons like high cost and environment pollution. Instead, they only rely on China as the dominant source of REs supply because REs import price is lower than extracting the raw materials from their grounds to produce REs products. Thus the current situation of excessive reliance on a single supplier will neither being able to meet nor sustain the increasingly REs demand in the future.

Table 1. World mine production and reserves (metric tons, REO)

\begin{tabular}{llll}
\hline & \multicolumn{2}{l}{${ }^{\mathrm{e} M i n e}$ production } & \\
\cline { 2 - 3 } & \multicolumn{2}{l}{ Reserves } \\
\hline United States & - & - & 13000000 \\
Australia & - & - & 1600000 \\
Brazil & 550 & 550 & 48000 \\
China & 130000 & 130000 & 55000000 \\
Commonwealth of Independent States & NA & NA & 19000000 \\
India & 2800 & 3000 & 3100000 \\
Malaysia & 30 & 30 & 30000 \\
Other countries & NA & NA & 22000000 \\
World total (rounded) & 133000 & 133000 & 110000000 \\
\hline
\end{tabular}

Source: Cordier (2012).

Notes: ${ }^{\mathrm{e}}$ Estimated. NA Not available. - Zero. ${ }^{1}$ That part of the reserve base which could be economically extracted or produced at the time of determination. The term reserves need not signify that extraction facilities are in place and operative. Reserves include only recoverable materials; thus, terms such as "extractable reserves" and "recoverable reserves" are redundant and are not a part of this classification system.

The global RE supply and demand situation in 2011 is presented in Figure1 below. It is obvious that a shortage (rounded 4000 metric tons, REO) has appeared in the global REs supply. It seems that the shortage is not large, but the gap between REs supply and demand will increasingly expand if China keeps being the dominant position as REs supplier. 57\% of global REs demand is from China, so China has to restrict the exports to other countries so as to satisfy internal demand first. As shown in Figure 1, China's REs exports only satisfied 27\% of ROW's demand in 2011. Besides other REs producers such as India, the remaining demands are mainly fulfilled by either their own stockpiles or the smuggling out of China. In 2007, about $20 \%$ of the officially published REs export volumes were smuggled out of China (Gschneidner, 2011). 


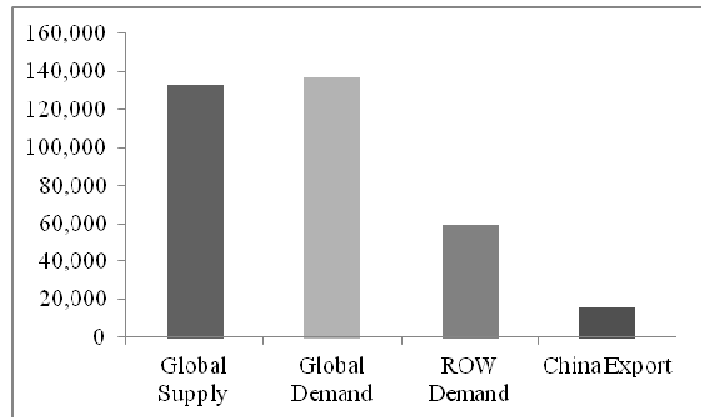

Figure 1. REs supply and demand in 2011 (data in metric tons of REO content)

Source: Roland Berger Strategy Consultants (2012), Cordier (2012), Jin (2011), Department of Industry of National Development and Reform Commission P.R. China [NDRC] (2012).

\subsection{Individual Rare Earth Elements (REEs)}

The total supply of global REs has trended to a deficit. However, the complication in REs supply and demand calculation is that there are 17 REEs and each has different end uses and produced in different quantities according to the different reserves and extraction processes. Thus the supply and demand of each REE needs to be analyzed respectively.

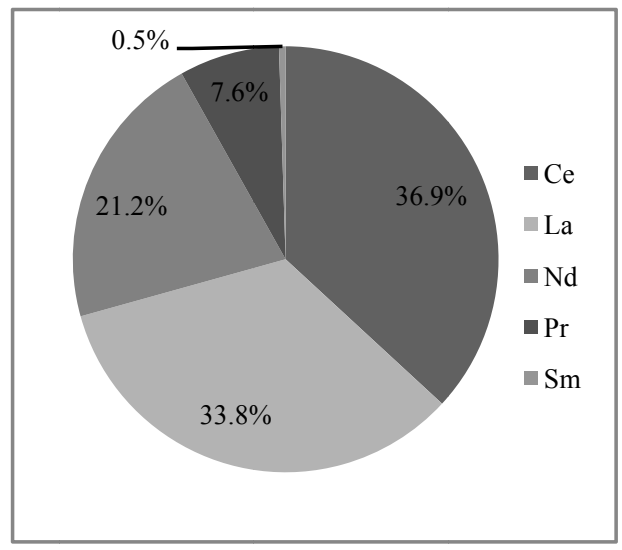

Figure 2. LREEs demands in 2011

Source: Roland Berger Strategy Consultants (2012).

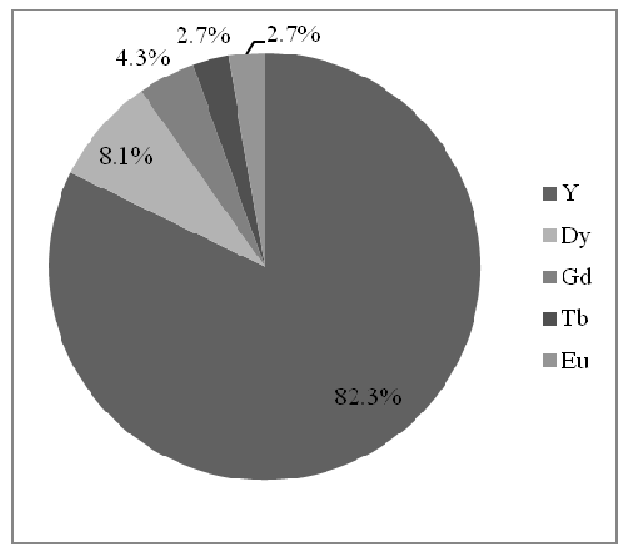

Figure 3. HREEs demands in 2011

Source: Roland Berger Strategy Consultants (2012).

Both Figure 2 and Figure 3 show the demands of light REEs (LREEs) and heavy REEs (HREEs) in 2011. Ce, La and $\mathrm{Nd}$ in the LREEs reach $92 \%$ of the total LREEs demands, while the market share of Y and Dy is over $90 \%$ in the HREEs. $92 \%$ of LREEs are mainly applied for polishing power, magnets and catalysts, while $90 \%$ of 
HREEs are for ceramics, magnets and phosphors.

Under the huge demands for these main REEs, most supplies, however, cannot satisfy them. In the LREEs, Nd is in a $57 \%$ supply deficit while $\mathrm{Ce}$ is in a surplus. Others keep the current balance. According to REEs' applications, magnets, as the main end application of $\mathrm{Nd}$, are in the shortage. However, magnets are one of the most important REEs end usages, so the shortage of $\mathrm{Nd}$ is the big shock to the magnets. In the HREEs, none of the elements is in surplus because they have much less reserves than LREEs and are produced only in southern China but have various applications. Since the Chinese government reduced plenty of HREEs export quota, a severe shortage of HREEs is showed in the ROW and there is no alternatives to these elements.

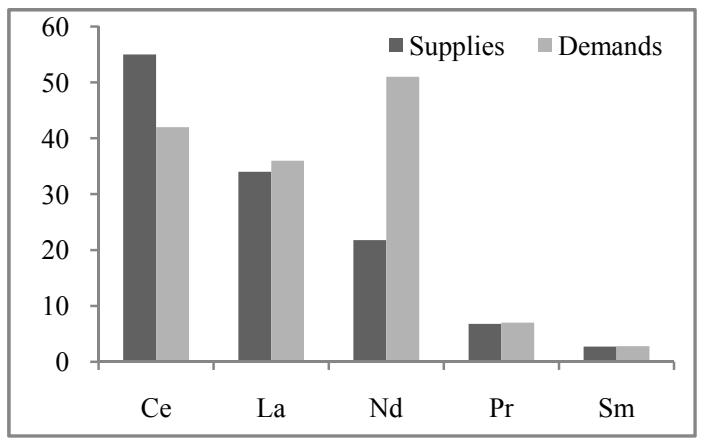

Figure 4. LREEs supply and demand in 2010 (thousands of metric tons)

Source: Gschneidner (2011).

Note: Ce includes the wasted parts in the extraction process.

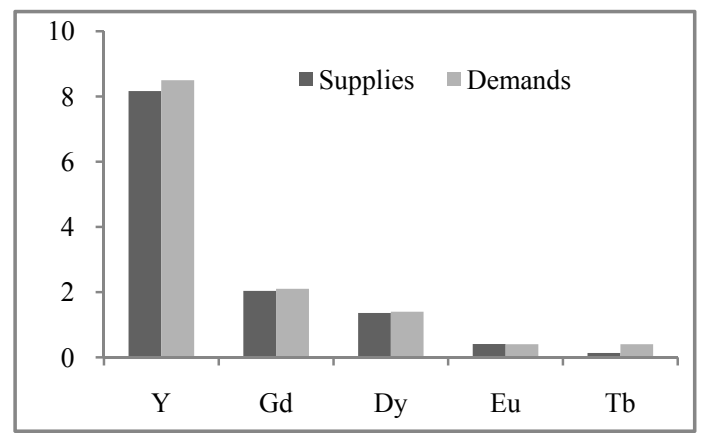

Figure 5. HREEs supply and demand in 2010 (thousands of metric tons)

Source: Gschneidner (2011).

Thus, in order to control the shortages of REEs especially the HREEs, many countries make various deficit risk mitigation strategies such as stockpile accumulation and efficient recycling of REs materials. However, those strategies still cannot work effectively due to the increasingly demands if China's monopoly of REs productions cannot be broken. Thus it is urgent for ROW to develop the other half of global REs reserves especially U.S. and Austria.

\section{U.S.'s Reaction to REs Supply Crisis: Re-Emerging of Its REs Industry}

Because of the current global REs supply shortage, countries with REs reserves have planned to tap into their own reserves, which they think is the best strategy to satiate growing demand and to counteract the risks of further supply restrictions. This strategy also can promote the healthy development of global REs markets. U.S. is the starter of this activity by virtue of its rich REs reserves and glorious history as the biggest REs producer. Its Mountain Pass has reopened at the end of 2012.

Table 2 shows the three main emerging REs production mines in U.S. according to REs resource reliability evaluated by Szumigala (2010). Mountain Pass mine, which is the main supplier of the U.S. and world in the last century, has re-produced since 2012 and mainly supplies LREEs such as La, Ce, Nd. Bear Lodge is under the preliminary economic assessment now and the main REEs it supplies are similar to the Mountain Pass mine but the contained REO reserves are only $22 \%$ of that mine. Bokan Mountain, though is under the metallurgical testwork now, is the most important source of HREEs in U.S. which keeps 17\% HREEs share, especially the element Y reserves. Thus, the opening of this mine will efficiently mitigate the serious HREEs shortage. 
Table 2. Selected emerging REs production mines in U.S.

\begin{tabular}{lllllll}
\hline Company & Deposit & $\begin{array}{l}\text { Planned start of } \\
\text { production }\end{array}$ & $\begin{array}{l}\text { Contained total REO } \\
\text { (metric tons) }\end{array}$ & $\begin{array}{l}\text { HREEs } \\
\text { share }\end{array}$ & $\begin{array}{l}\text { 2015-2016 production } \\
\text { (metric tons) }\end{array}$ & Main REEs \\
\hline Molycorp Inc. & $\begin{array}{l}\text { Mountain } \\
\text { Pass }\end{array}$ & 2012 & $1800000(9.2 \%)$ & $1 \%$ & 40000 & $\begin{array}{l}\mathrm{La}, \mathrm{Ce}, \mathrm{Nd}, \mathrm{Pr}, \\
\mathrm{Sm}\end{array}$ \\
$\begin{array}{l}\text { Rare Element } \\
\text { Bear Lodge }\end{array}$ & 2015 & $400000(4.1 \%)$ & $2 \%$ & 10000 & $\begin{array}{l}\mathrm{Ce}, \mathrm{La}, \mathrm{Nd}, \mathrm{Pr}, \\
\mathrm{Sm}\end{array}$ \\
$\begin{array}{l}\text { Resources Ltd. } \\
\begin{array}{l}\text { Ucore Rare Metals } \\
\text { Inc. }\end{array}\end{array}$ & $\begin{array}{l}\text { Bokan } \\
\text { Mountain }\end{array}$ & $2014-16$ & $300000(0.75 \%)$ & $17 \%$ & $\mathrm{NA}$ & $\begin{array}{l}\mathrm{Ce}, \mathrm{Y}, \mathrm{La}, \mathrm{Nd}, \\
\mathrm{Sm}, \mathrm{Gd}, \mathrm{Dy}\end{array}$ \\
\hline
\end{tabular}

Source: Nestour (2011), Roland Berger Strategy Consultants (2012), Ucore Rare Metals Inc. (2011), Kingsnorth (2011), Schüler, Buchert, Liu, Dittrich \& Merz (2011), Long (2011), Chen (2011).

\section{Potential Impact of U.S. REs Industry on Future Global REs Supply and Demand}

\subsection{Impact on Global and China's REs Supply and Demand}

Kingsnorth, Dudley J. (2012), a world-recognized expert on the RE market has forecasted the global REs supply and demand trend in 2016. The collected data are showed in Figure 6.

According to his forecast, U.S. demands for REs will reach 23500 tonnes in 2016. Thus, the outputs (approximately 50000 tonnes) of the three emerging U.S. REs mines mentioned above can meet its internal needs and will still have over $50 \%$ excess productions which can be exported to other countries. Furthermore, the REs demands of ROW (excluding U.S.) will be 32500 tonnes so that U.S. REs exports can meet 82\%. By contrast, in 2016, it is forecasted that only 35\% of China's REs outputs will be supplied to ROW (excluding U.S. because it has enough internal REs) due to its increasing internal demands (almost $65 \%$ for internal consumption). Therefore, U.S. will become the main REs export country again, but is no longer the importer of China's REs and China's REs are mainly used for own consumption. In other words, China will not be the monopoly of REs markets any more from the total amounts of all the REEs, while U.S. will control its internal REs market and occupy considerable international market in 2016.

In addition, the total REs exports from both top REs producers will exceed $50 \%$ of the demands of ROW in 2016, let alone plus the exports from other REs producers. It also indicates a substantial surplus in the global REs supply in 2016.

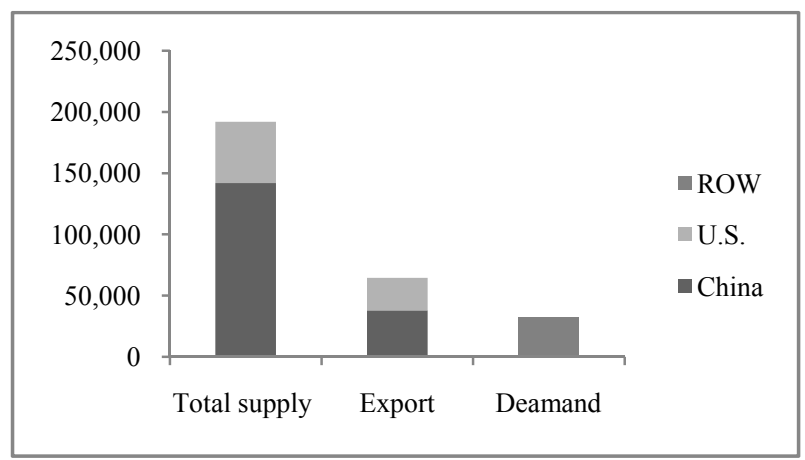

Figure 6. Forecast to U.S. and China's REs supplies in 2016 (metric tons, REO $\pm 20 \%$ )

Source: Kingsnorth (2012).

Notes: ROW: rest of the world (excluding China and U.S.); Total supply: total outputs of REs in 2016.

It is easy to find from Figure 6 that China's exports can still meet the ROW (excluding China and U.S.) REs demands in 2016 even if there is no supply out of China. Then the question rises whether the substantial surplus of the global REs supply in total output means that U.S. will lead the global REs market into the other supply extreme in future. The answer is no. U.S. REs supply can adjust the current distorted global REs markets that most countries excessive rely on China's REs export by means of occupying and expanding its market share in REs trade. The final purpose is to lead the global REs industry to the balanced tendency of supply and demand. It is forecasted that ROW will be able to supply $100 \%$ of their demand in 2020 (Kingsnorth, 2012). That is to say, the REs supply diversification partly contributed by U.S. will lead to the global balance of REs supply and 
demand eventually. Moreover, it also balances the reserves and outputs of China's REs so that China's REs resources can maintain the sustainable development.

\subsection{Impact on Individual REEs Demands}

According to the overview of the global individual REEs supply and demand in 2010 in part 2, five REEs are in a supply deficit, i.e. Nd, Y, Dy, Eu, Tb. Except the element Nd, other four elements are all HREEs. The development of U.S. REs mines mitigates this shortage crisis to some extent. However, as shown in Table 3, the U.S. REEs supply has little impact on deficient REEs demands except the LREE Nd which U.S. can satisfy $57 \%$ of demands outside China. Thus, U.S. re-emerging REs industry will still not be able to influence the dominant position of China's HREEs supplies especially these four deficient REEs in future.

Table 3. Impact of U.S. supplies on ROW deficient REEs demands (metric tons REO $\pm 20 \%$ )

\begin{tabular}{lllll}
\hline REE & ROW demand & U.S. REEs supply & & Total output \\
\cline { 3 - 5 } & & Mountain Pass & Bear Lodge & 6060 \\
\hline $\mathrm{Nd}$ & 10602 & 4480 & 1580 & 40 \\
$\mathrm{Y}$ & 8322 & 40 & 0 & 20 \\
$\mathrm{Dy}$ & 400 & 0 & 20 & 80 \\
$\mathrm{Eu}$ & 171.5 & 40 & 40 & 10 \\
$\mathrm{~Tb}$ & 177 & 0 & 10 & \\
\hline
\end{tabular}

Source: Nestour (2011), Chen (2011), Long (2011), Kingsnorth (2012), Long, Gosen, Foley \& Cordier (2010).

Except the four short HREEs, as shown in Table 4, other REEs demands of ROW will be predominantly influenced by U.S. re-emerging REs industry. Especially the element $\mathrm{Sm}$ which used for the magnets will be in a low supply surplus. Furthermore, the sufficient supply of these REEs showed in Table 4 from U.S. will also promote the development of those corresponding REEs application products, such as fluid catalytic cracking, polishing powder and magnets.

Table 4. Impact of U.S. supplies on other REEs demands of ROW (metric tons REO $\pm 20 \%$ )

\begin{tabular}{lllll}
\hline REE & ROW demand & U.S. REEs supply & \\
\cline { 3 - 5 } & & Mountain Pass & Bear Lodge & Total output \\
\hline $\mathrm{La}$ & 20617.5 & 13520 & 3040 & 16560 \\
$\mathrm{Ce}$ & 27273 & 19840 & 4550 & 24390 \\
$\mathrm{Pr}$ & 3803 & 1640 & 470 & 2110 \\
$\mathrm{Sm}$ & 511 & 360 & 180 & 540 \\
$\mathrm{Gd}$ & 363 & 80 & 70 & 150 \\
Other & 120 & 0 & 50 & 50 \\
\hline
\end{tabular}

Source: Nestour (2011), Chen (2011), Long (2011), Kingsnorth (2012), Long et al. (2010).

Note: *only the output of the element $\mathrm{Yb}$.

As discussed in this part, it is obvious that U.S. re-emerging REs mines will mainly influence the LREEs demands outside China, while China will still keep its monopoly position of HREEs supply due to its role as the unique origin of the most minable HREEs resources.

\section{Conclusion}

U.S. re-emerging REs industry will have a significant impact on future global and its internal REs demands. In future, global REs will be in surplus in total inevitably. Thus, some industries whose products need plenty of REs will make a better development. China's monopoly of REs minerals market will be broken and there will be diversified suppliers, which will also push the REs prices back on the right track in the future global REs markets.

However, the positive impact of U.S. re-emerging REs industry will only be on the LREEs, while the HREEs supplies will still rely heavily on China. This is the advantage of resource endowment China holds on HREEs. Therefore, China should make good use of this resource advantages by means of effective implement of REs industry policies. U.S. should mainly ensure its internal REs demands through exploiting and mining its rich REs ore, especially the HREEs ore such as Bokan Mountain which is a new hope for U.S. to be independent of China's export totally. 


\section{Acknowledgements}

The authors would like to thank anonymous reviewers for their valuable comments and sincerely express thanks for the support from the National Natural Science Foundation of China under Grant No.71241027 and the support from the Fundamental Research Funds for the Central Universities under Grant No.2011YXS057.

\section{References}

Bailey, K. (1994). Methods of Social Research (4th ed.). New York: The Free Press.

Chen, Z. H. (2011). Global rare earth resources and scenarios of future rare earth industry. Journal of Rare Earths, 29(1), 1-6. http://dx.doi.org/ 10.1016/S1002-0721(10)60401-2

Cordier, D. J. (2012). U.S. Geological Survey, Mineral Commodity Summaries. Retrieved from http://minerals.usgs.gov/minerals/pubs/commodity/rare_earths/mcs-2012-raree.pdf

Currie, A. (2012, April 23). Overview of Molycorp Californian Rare Earth Deposit. Retrived January 25, 2013 from

http://rareearthinvestingnews.com/6796-overview-moylcorp-californian-rare-earth-deposit-mountain-pass-p roject-phoenix.html

Department of Industry of National Development and Reform Commission P.R. China [NDRC]. (2012). China's Rare Earths-2011. Rare Earth Information, 4, 4-8. (in Chinese)

Gschneidner, K. A. Jr. (2011). The Rare Earth Crisis-The Supply/Demand Situation for 2010-2015. Materials Matters, 6(2), 32-37.

Hendrick, J. B., \& Cordier, D. J. (2010). 2008 Minerals Yearbook: Rare Earths. Retrieved from http://minerals.usgs.gov/minerals/pubs/commodity/rare_earths/myb1-2008-raree.pdf

Jin, T. (2011). Export Regulation and Optimal Export Quota Design of Rare-Earth. Zhejiang Social Sciences, 12 , 62-67 \& 155. (in Chinese)

Kingsnorth, D. J. (2011). Meeting the Challenges of Supply this Decade [PowerPoint slides]. Retrieved from http://files.eesi.org/kingsnorth_031111.pdf

Kingsnorth, D. J. (2012). The Global Rare Earths Industry: A Delicate Balancing Act [PowerPoint slides]. Retrieved from http://www.deutsche-rohstoffagentur.de/DERA/DE/Downloads/RD_kingsnorth_2012.pdf?_blob=publicati onFile \& $v=2$

Long, K. R. (2011). The Future of Rare Earth Elements-Will These High-Tech Industry Elements Continue in Short Supply? [PowerPoint slides]. Retrieved from http://pubs.usgs.gov/of/2011/1189/of2011-1189.pptx.pdf

Long, K. R., Gosen, B. S., Van, Foley, N. K., \& Cordier, D. (2010). The Principal Rare Earth Elements Deposits of the United State-A Summary of Domestic Deposits and a Global Perspective. Retrieved from http://pubs.usgs.gov/sir/2010/5220/downloads/SIR10-5220.pdf

Morrison, W. M., \& Tang, R. (2012, April 30). China's Rare Earth Industry and Export Regime: Economic and Trade Implications for the United States. Congressional Research Service Report.

Nestour, M. (2011, April). Technology minerals-The rare earths race is on! New York: Ernst \& Young.

Roland Berger Strategy Consultants. (2012). The Rare Earth Challenge-How Companies React and What they Expect for the Future [PowerPoint slides]. Retrieved from http://www.pressebox.de/attachment/414611/The+Rare+Earth+challenge_final.pdf

Schüler, D., Buchert, M., Liu, R., Dittrich, S., \& Merz, C. (2011, January). Study on Rare Earths and Their Recycling (Final Report). Darmstadt: The Greens/EFA Group in the European Parliament.

Scott, J. (1990). A Matter of Record: Documentary Sources in Social Research. Cambridge: Polity Press.

Szumigala, D. (2011, February 2). Rare Earth Elements - A Brief Overview of these elements, including their uses, worldwide resources and known occurrences in Alaska. Fairbanks: Alaska Division of Geological \& Geophysical Surveys.

Ucore Rare Metals Inc. (2011). For US Dysprosium Self Sufficiency [PowerPoint slides]. Retrieved from http://ucore.com/Ucore_TREM.pdf 


\section{Copyrights}

Copyright for this article is retained by the author(s), with first publication rights granted to the journal.

This is an open-access article distributed under the terms and conditions of the Creative Commons Attribution license (http://creativecommons.org/licenses/by/3.0/). 